Article

\title{
Speciation and Determination of Selenium Oxyanions at the Drinking Water Pollution Concentration Levels
}

\author{
Kyriaki Kalaitzidou $^{1}$ (D), Evangelia Bidiou ${ }^{2}$, Anastasios Zouboulis ${ }^{2, *}$ iD and Manassis Mitrakas ${ }^{1}$ \\ 1 Department of Chemical Engineering, Aristotle University of Thessaloniki, 54124 Thessaloniki, Greece; \\ kikalaitz@geo.auth.gr (K.K.); mmitraka@auth.gr (M.M.) \\ 2 Department of Chemistry, Aristotle University of Thessaloniki, 54124 Thessaloniki, Greece; \\ ekmpidiou@gmail.com \\ * Correspondence: zoubouli@chem.auth.gr; Tel.: +30-2310-997794
}

Citation: Kalaitzidou, K.; Bidiou, E.; Zouboulis, A.; Mitrakas, M. Speciation and Determination of Selenium Oxyanions at the Drinking Water Pollution Concentration Levels. Separations 2021, 8, 27. https:// doi.org/10.3390/separations8030027

Academic Editor: Victoria Samanidou

Received: 23 January 2021

Accepted: 24 February 2021

Published: 1 March 2021

Publisher's Note: MDPI stays neutral with regard to jurisdictional claims in published maps and institutional affiliations.

Copyright: (c) 2021 by the authors. Licensee MDPI, Basel, Switzerland. This article is an open access article distributed under the terms and conditions of the Creative Commons Attribution (CC BY) license (https:// creativecommons.org/licenses/by/ $4.0 /)$.

\begin{abstract}
The research on selenium presence in water resources has revealed the need to determine the respective aquatic species. As selenium oxyanions $\mathrm{SeO}_{3}{ }^{2-}\left(\mathrm{Se}^{\mathrm{IV}}\right)$ and $\mathrm{SeO}_{4}{ }^{2-}\left(\mathrm{Se}^{\mathrm{VI}}\right)$ predominate in natural waters, their determination is essential, mainly due to different ecotoxicity properties, as well as to different removal options from relevant-polluted waters. This study focuses on the $\mathrm{SeO}_{3}{ }^{2-} / \mathrm{SeO}_{4}{ }^{2-}$ speciation/separation and determination through the selective adsorption of $\mathrm{SeO}_{3}{ }^{2-}$ only onto specific iron oxy-hydroxides (FeOOHs). For this purpose, the laboratory prepared FeOOHs examined along with the commercially available relevant material (Bayoxide), which was found to present optimum results for the speciation of selenium oxyanions, at the low concentration range $10-100 \mu \mathrm{g} / \mathrm{L}$, using a dose of $0.5 \mathrm{~g} / \mathrm{L}$ of adsorbent and gently stirring for $30 \mathrm{~min}$ at the usually encountered $\mathrm{pH}$ value of $7.3 \pm 0.2$. Moreover, the relevant experiments showed that the other major ions $\mathrm{Cl}^{-}, \mathrm{HCO}_{3}{ }^{-}, \mathrm{NO}_{3}{ }^{-}, \mathrm{SO}_{4}{ }^{2-}, \mathrm{Ca}^{2+}, \mathrm{Mg}^{2+}, \mathrm{Na}^{+}$, possibly found in most natural waters at the concentration range $0-200 \mathrm{mg} / \mathrm{L}$, as well as silicon, total organic carbon (TOC) of natural organic matter (NOM) and iron at the concentration range $0-50 \mathrm{mg} / \mathrm{L}, 0-5 \mathrm{mg} / \mathrm{L}$ and $0-1 \mathrm{mg} / \mathrm{L}$, respectively, did not interfere with the selective adsorption of Se(IV). Furthermore, the most important advantage of this selective speciation method is its implementation/combination with all commonly applied analytical methods for the determination of total selenium.
\end{abstract}

Keywords: Se(IV)-Se(VI) speciation; separation and determination; adsorption; iron oxy-hydroxides; natural waters

\section{Introduction}

The Swedish chemist Jöns Jacob Berzelius was the first scientist to discover selenium in 1817. Selenium can be found in natural water mainly with its inorganic forms, presenting various oxidative valent stages (i.e., - II, 0, IV, and VI), as well as (in trace levels) complexed with various organic forms, such as methylated compounds, seleno-amino acids and seleno-proteins [1]. However, the major forms encountered in most natural waters are the respective oxyanions of IV and VI valent states. Selenium is considered an essential nutrient for human growth at the concentration range within the drinking water regulation limits [2-4]; nevertheless, the long-term exposure to relatively higher concentrations (e.g., through potentially polluted drinking water sources) can cause severe toxic effects, due to its bioaccumulation [5].

In aquatic ecosystems (including groundwater), where the $\mathrm{pH}$ values usually range between 6 and 8 , the most commonly encountered chemical species of selenium are the oxyanion forms, i.e., $\mathrm{SeO}_{3}{ }^{2-}\left(\mathrm{Se}^{\mathrm{IV}}\right)$ and $\mathrm{SeO}_{4}{ }^{2-}\left(\mathrm{Se}^{\mathrm{VI}}\right)$ [6]. Therefore, it is crucial to determine with high accuracy and precision the concentration of selenium species, in order to evaluate properly their corresponding ecotoxicity effects/differences in the aquatic environment [7]. Additionally, the selection of an appropriate drinking water treatment process, regarding the removal of selenium, should be also accordingly adapted to the specific 
oxyanion that dominates each potentially polluted water body, since these oxyanions are showing different removal efficiencies, depending on the specifically applied treatment method [8,9].

A wide variety of analytical methods is used to determine the concentration of total selenium, such as titration [10], gravimetric methods [11], colorimetric methods [12], spectrophotometric methods [13], fluorometry [14], hydride generation-atomic absorption spectrometry [15], graphite furnace-atomic absorption spectrometry [16], inductively-coupled plasma atomic emission spectrometry (ICP-AES) [17], inductively-coupled plasma mass spectrometry (ICP-MS) [18], and isotope dilution-mass spectrometry [19]. The plethora of analytical options, available for the determination of total selenium, allows the analysts to apply the method most compatible with the available equipment in each laboratory.

Several analytical techniques have been applied for the speciation of Se, presenting different drawbacks that need to be carefully considered. For example, gas chromatography is usually incompatible with applications regarding natural water samples, because the usually applied fractionation may require the appropriate pre-treatment of different selenium oxyanions by applying organic/toxic solvents, possibly producing piazselenols, which may not be determined accurately, due to their high volatility. The use of HighPressure Liquid Chromatography (HPLC) method as a separation technique for selenium species takes usually more than $10 \mathrm{~min}$ to separate the selenium oxyanions. Thus, when HPLC is combined, e.g., with ICP-MS (LOD 1.2 and $1.4 \mu \mathrm{g} / \mathrm{L}$ for Se(IV) and Se(VI), respectively [20]) for the determination of selenium species, it requires approximately 1 min for each sample determination, and therefore, the total time for each sample pre-treatment and determination can overpass $10 \mathrm{~min}$. In addition, this hybrid HPLC-ICP-MS method also presents higher operating cost per sample and capital cost one order of magnitude higher, when compared to GF-AAS [21]. Additionally, the selenium hydride generation performed within $\sim 15 \mathrm{~min}$, as applied in field studies by Omanovic et al. (2002), requires an additional 5-15 min to reduce $\mathrm{SeO}_{4}{ }^{2-}$ to $\mathrm{SeO}_{3}{ }^{2-}$ in a microwave digestion system, while the Supralab FD pre-treatment device for selenium determination uses a filter that requires subsequent drying for $\sim 45 \mathrm{~min}$, resulting in a significantly time-consuming procedure [22]. Capillary electrophoresis is an energy-consuming process that is usually hyphenated with ICP-MS. Deng et al. (2007) used a fused silica capillary (with sample throughput $\sim 3 \mathrm{~min}$ ) and reported selenium recoveries of 91-108\%, using tap and river spiked water samples [23]. The selective sequential hydride generation and photochemical vapor pressure also require quite complicated and time-consuming pre-treatment steps with a prolonged pre-heating, or UV-irradiation for the Se(VI) reduction to Se(IV), producing volatile Se, due to UV irradiation, reducing the reliability of the analysis and resulting in substantial increase in cost, as they are usually combined with ICP-MS. Liquid-liquid micro-extraction is a more complex procedure, due to the production of piazselenols and requires the use of organic solvents that are toxic, while, at the same time, is a time-consuming determination method, as the procedure most usually requires a heating step at $100{ }^{\circ} \mathrm{C}$. In addition, the solid phase micro-extraction, in which the adsorption step is followed by the extraction of adsorbed species, generates accuracy and precision issues. Liquid-liquid micro-extraction and solid phase micro-extraction are also usually combined with the application of ICP-MS [24,25].

Therefore, the development of a speciation method, aiming to the selective and quantitative separation of selenium oxyanions that would be simple, cost effective, rapid, sensitive, and compatible with the majority of modern analytical determination instrumentation, is considered as crucial. For this purpose, batch adsorption experiments were conducted, using iron oxy-hydroxides (FeOOHs), to examine the selective uptake and quantitative separation of $\mathrm{SeO}_{3}{ }^{2-}$ against $\mathrm{SeO}_{4}{ }^{2-}$ from natural water samples. Although the FeOOHs have been previously examined for selenium removal [8], the obtained results showed the lack of $100 \%$ selective adsorption for selenium oxyanions. In addition, several other studies [26-32] have reported the removal of both $\mathrm{SeO}_{3}{ }^{2-}$ and $\mathrm{SeO}_{4}{ }^{2-}$ and the absence of effective separation between these species. Based upon the better affinity of FeOOHs against the $\mathrm{SeO}_{3}{ }^{2-}$ rather than $\mathrm{SeO}_{4}{ }^{2-}$, and their relatively low cost, the qualified $\mathrm{FeOOH}$ 
was verified, aiming to make this material the proper one for the selective uptake of Se(IV) by adsorption.

\section{Materials and Methods}

\subsection{Reagents}

Stock solutions of Se(IV) and Se(VI) were prepared from the analytical grade reagents $\mathrm{Na}_{2} \mathrm{SeO}_{3}$ (supplied by ACROS Organics, anhydrous 44-46\% purity) and $\mathrm{NaSeO}_{4}$ (supplied by Alfa Aesar, anhydrous $>99.8 \%$ purity), respectively, dissolved in distilled water. Stock solutions of $\mathrm{Cl}^{-}, \mathrm{HCO}_{3}{ }^{-}, \mathrm{NO}_{3}{ }^{-}, \mathrm{SO}_{4}{ }^{2-}, \mathrm{Si}, \mathrm{Ca}^{2+}, \mathrm{Mg}^{2+}$, and $\mathrm{Na}^{+}$were prepared from the respective analytical grade reagents, i.e., $\mathrm{NaCl}$ (supplied by Merck, $>99.0 \%$ purity), $\mathrm{NaHCO}_{3}$ (supplied by Merck, $>99.5 \%$ purity), $\mathrm{NaNO}_{3}$ (supplied by Merck, >99.5\% purity), $\mathrm{Na}_{2} \mathrm{SO}_{4}$ (supplied by Merck, $>99.0 \%$ purity), $\mathrm{NaSiO}_{3} \cdot 5 \mathrm{H}_{2} \mathrm{O}$ (supplied by Loufakis Chemicals S.A., $>99.0 \%$ purity), $\mathrm{CaCl}_{2} \cdot 2 \mathrm{H}_{2} \mathrm{O}$ (supplied by Riedel-de Haen, $>99.0$ purity $\mathrm{MgSO}_{4} \cdot 7 \mathrm{H}_{2} \mathrm{O}$ (supplied by Panreac, $>98.0 \%$ purity), and $\mathrm{NaCl}$, dissolved in distilled water. The $100 \mathrm{mg} \mathrm{Fe}{ }^{2+} / \mathrm{L}$ stock solution was prepared by diluting in $1 \mathrm{~L}$ of distilled water $0.51 \mathrm{~g}$ of $\mathrm{FeSO}_{4} \cdot 7 \mathrm{H}_{2} \mathrm{O}$ (supplied by Riedel de Haen, $>99 \%$ purity), which was pre-treated to remove residual oxygen content with the supply of $\mathrm{N}_{2}$ gas.

The natural test water was prepared according to the National Sanitation Foundation (NSF) standard, containing $252 \mathrm{mg} \mathrm{NaHCO} 3,12.14 \mathrm{mg} \mathrm{NaNO}, 0.178 \mathrm{mg} \mathrm{NaH} \mathrm{NO}_{4} \cdot \mathrm{H}_{2} \mathrm{O}$ (supplied by Sigma-Aldrich, $>98.0 \%$ purity), $2.21 \mathrm{mg} \mathrm{NaF}$ (supplied by Merck, $>99.0 \%$ purity), $70.6 \mathrm{mg} \mathrm{NaSiO} \cdot 5 \mathrm{H}_{2} \mathrm{O}, 147 \mathrm{mg} \mathrm{CaCl} 2 \cdot 2 \mathrm{H}_{2} \mathrm{O}$, and $128.3 \mathrm{mg} \mathrm{MgSO} \cdot \cdot 7 \mathrm{H}_{2} \mathrm{O}$, diluted in $1 \mathrm{~L}$ of distilled water and the corresponding ion concentrations are shown in Table 1 [33]. The stock solution of humic acid was prepared by dissolving $1 \mathrm{~g}$ of reagent grade humic acid powder (supplied by Sigma-Aldrich, No. 53680) into $500 \mathrm{~mL}$ distilled water. The $\mathrm{pH}$ of this solution was adjusted to 12 with $1 \mathrm{~N} \mathrm{NaOH}$ (prepared by sodium hydroxide pellets supplied by Chem-Lab, $>99.0 \%$ purity), and then, the solution was filtered through a cellulose acetate membrane (MFS) of $0.45 \mu \mathrm{m}$ pore size. The supernatant was collected and adjusted to neutral $\mathrm{pH}$ with $\mathrm{HCl}$ (supplied by Chem-Lab, 37\% purity) and transferred in a plastic bottle for storage. Experimental solutions of the desired humic acid concentrations were obtained by successive dilutions. Working standards of Se(IV) and Se(VI) were prepared by the proper dilution of stock solutions into the NSF water matrix. All working solutions were prepared at least $12 \mathrm{~h}$ before the adsorption tests to allow sufficient time for the integration of selenium oxyanions into the water matrix and permitting to form similar species as those found in natural waters.

Table 1. Ion concentrations in the NSF water matrix, simulating natural water used for experiments.

\begin{tabular}{cccc}
\hline Cations & $\mathbf{m g} / \mathrm{L}$ & Anions & $\mathrm{mg} / \mathrm{L}$ \\
\hline $\mathrm{Na}^{+}$ & 88.8 & $\mathrm{HCO}_{3}{ }^{-}$ & 138 \\
$\mathrm{Ca}^{2+}$ & 40.0 & $\mathrm{SO}_{4}{ }^{--}$ & 50 \\
$\mathbf{M g}^{2+}$ & 12.7 & $\mathrm{Cl}^{-}$ & 71 \\
& & $\mathrm{~N}^{-} \mathrm{NO}_{3}{ }^{-}$ & 2 \\
& & $\mathrm{~F}^{-}$ & 1 \\
& & $\mathrm{P}^{3} \mathrm{PO}_{4}{ }^{3-}$ & 0.04 \\
& & $\mathrm{Si} / \mathrm{SiO}_{2}$ & $10.5 / 22.4$ \\
\hline
\end{tabular}

\subsection{Adsorbents}

The examined iron oxy-hydroxides (FeOOHs) were prepared at kilogram scale using a laboratory two-stage continuous flow reactor (CSTR-1 and CSTR-2) with each stage having $1 \mathrm{~h}$ retention time, similar to the procedure described in the respective literature [34]. The preparation procedure included a sequence of $\mathrm{Fe}(\mathrm{II})$ oxidation $\left(\mathrm{FeSO}_{4} \cdot \mathrm{H}_{2} \mathrm{O}\right.$ supplied by Loufakis Chemicals S.A.), hydrolysis, and subsequent Fe(III) precipitation (as FeOOH) in aqueous environment at high redox value conditions $(250-600 \mathrm{mV})$ and application of a wide range of $\mathrm{pH}$ values. Along with the laboratory-synthesized iron oxy-hydroxides, the commercially available Bayoxide, consisting mainly from goethite $(\alpha-\mathrm{FeOOH})$ and 
produced by LANXESS Deutschland $\mathrm{GmbH}$, was also comparatively examined for the selective separation of selenite. The main physicochemical parameters of these adsorbents are previously described [8] and summarized in Table 2, noting that the experimental procedures followed for the determination of these characteristics are described in Text S1 in the Supplementary Material.

Table 2. The main physicochemical characteristics of laboratory-synthesized and commercial adsorbents based on FeOOHs and used in this study for the separation of selenium species.

\begin{tabular}{|c|c|c|c|c|c|c|c|c|}
\hline \multicolumn{4}{|c|}{ Synthesis Parameters } & \multicolumn{5}{|c|}{ Physicochemical Characteristics } \\
\hline Abbreviation & Materials & $\mathrm{pH}$ & $\begin{array}{c}\text { ORP } 1 \\
(\mathrm{mV})\end{array}$ & $\begin{array}{c}\text { Fe } \\
\text { wt. } \%\end{array}$ & $\begin{array}{c}\text { Surface Area } \\
\left(\mathrm{m}^{2} / \mathrm{g}\right)\end{array}$ & IEP $^{2}$ & $\mathrm{ZPC}^{3}$ & $\begin{array}{c}\text { PSCD }^{4} \\
\mathrm{mmol}^{\left[\mathrm{OH}^{-}\right] / \mathrm{g}}\end{array}$ \\
\hline $\mathrm{FeOOH} / 2.5$ & $\mathrm{FeSO}_{4} / \mathrm{H}_{2} \mathrm{O}_{2}$ & 2.5 & 600 & 44.8 & 48 & 6.9 & 2.7 & 3.25 \\
\hline $\mathrm{FeOOH} / 4$ & $\mathrm{FeSO}_{4} / \mathrm{H}_{2} \mathrm{O}_{2}$ & 4.0 & 380 & 50.4 & 120 & 7.1 & 3.2 & 2.23 \\
\hline $\mathrm{FeOOH} / 5.7$ & $\mathrm{FeSO}_{4} / \mathrm{H}_{2} \mathrm{O}_{2}$ & 5.7 & 380 & 50.1 & 168 & 7.3 & 4.2 & 1.42 \\
\hline $\mathrm{FeOOH} / 8$ & $\mathrm{FeSO}_{4} / \mathrm{H}_{2} \mathrm{O}_{2}$ & 8.0 & 250 & 50.2 & 226 & 6.6 & 7.9 & 1.04 \\
\hline Bayoxide & & & & 52.0 & 135 & 7.4 & 7.8 & 0.80 \\
\hline
\end{tabular}

${ }^{1}$ Oxidation-reduction potential. ${ }^{2}$ Isoelectric point. ${ }^{3}$ Point of zero charge [35]. ${ }^{4}$ Positive surface charge density.

\subsection{Experimental Procedure}

Quantities $(0.25-2 \mathrm{~g} \mathrm{FeOOH} / \mathrm{L})$ of finely powdered $(<63 \mu \mathrm{m})$ adsorbent samples were dispersed into $200 \mathrm{~mL}$ of selenium solution (in NSF water matrix), using $300 \mathrm{~mL}$ conical flasks and were stirred gently for $1 \mathrm{~h}$ contact time at $20^{\circ} \mathrm{C}$. The solution $\mathrm{pH}$ was adjusted with either $1 \mathrm{M} \mathrm{HCl}$ or $1 \mathrm{M} \mathrm{NaOH}$ to set/determine the optimum $\mathrm{pH}$ range. The subsequent solid/liquid separation was performed by filtration, using a common membrane filter of $0.45 \mu \mathrm{m}$, and the resulting solution was further analyzed to determine the selenium content.

Initially, all adsorbents were examined in three replicates at $1 \mathrm{~h}$ contact time and at the optimum $\mathrm{pH}$ value of $7.3 \pm 0.2$, while samples were received every $5,15,30$, and $60 \mathrm{~min}$ to determine the kinetics/equilibrium of selenium species adsorption. The adsorption of Se(IV) and Se(VI) was examined in the concentration range of 10-100 $\mu \mathrm{g} / \mathrm{L}$. The adsorbent that presented the optimal selectivity was further tested using additional adsorption experiments to clarify the interference of commonly co-existing ions in natural waters at various concentrations. Specifically, $0.5 \mathrm{~g}$ FeOOH/L of finely powdered $(<63 \mu \mathrm{m})$ adsorbent was dispersed into $200 \mathrm{~mL}$ of selenium solution in NSF water matrix with the addition of $25,50,100$, and $200 \mathrm{mg} / \mathrm{L}$ of $\mathrm{Cl}^{-}, \mathrm{HCO}_{3}{ }^{-}, \mathrm{NO}_{3}{ }^{-}, \mathrm{SO}_{4}{ }^{2-}, \mathrm{Ca}^{2+}, \mathrm{Mg}^{2+}$, and $\mathrm{Na}^{+}$ions or of $10,25,40$, and $50 \mathrm{mg} / \mathrm{L}$ of $\mathrm{Si}$ or of $1,2.5,4$, and $5 \mathrm{mg} / \mathrm{L}$ of humic acid that represents the presence of natural organic matter (NOM) or of $0.1,0.25,0.5$, and $1 \mathrm{mg} / \mathrm{L}$ of $\mathrm{Fe}^{2+}$ in $300 \mathrm{~mL}$ conical flasks that were stirred gently for $30 \mathrm{~min}$ at $20{ }^{\circ} \mathrm{C}$ and at $\mathrm{pH}$ value of $7.3 \pm 0.2$.

The initial and residual elemental concentrations of metals and silicon were determined either by Graphite Furnace or by Flame Atomic Absorption Spectrophotometry, using a PerkinElmer AAnalyst 800 instrument. The detection limits of calcium, magnesium, silicon, sodium, iron, and selenium were $50 \mu \mathrm{g} \mathrm{Ca} / \mathrm{L}, 10 \mu \mathrm{g} \mathrm{Mg} / \mathrm{L}, 2 \mathrm{mg} \mathrm{Si} / \mathrm{L}, 20 \mu \mathrm{g} \mathrm{Na} / \mathrm{L}$, $50 \mu \mathrm{g} \mathrm{Fe} / \mathrm{L}$, and $1 \mu \mathrm{g} \mathrm{Se} / \mathrm{L}$, respectively. In order to cross check the Se(IV) concentrations, the determination was also conducted by following the Ahmed et al. (2015) spectrophotometric analytical method (detection limit $1 \mu \mathrm{g} / \mathrm{L}$ ) [36], using the spectrometer UV-VIS HITACHI U-5100. Nitrate, chloride, and sulfate were measured with the Alltech 600 ion chromatography system, using an Allsep anion, $150 \mathrm{~mm} \times 4.6 \mathrm{~mm}, 7 \mu \mathrm{m}$, PEEK 51209 column and applying a $1.7 \mathrm{mM} \mathrm{NaHCO} / 1.8 \mathrm{mM} \mathrm{Na}_{2} \mathrm{CO}_{3}$ (supplied by Merck, >99.5\% purity) solution as eluent. The detection limits were $1 \mathrm{mg} \mathrm{NO}_{3}{ }^{-} / \mathrm{L}, 1 \mathrm{mg} \mathrm{SO}_{4}{ }^{2-} / \mathrm{L}$, and $1 \mathrm{mg} \mathrm{Cl}^{-} / \mathrm{L}$, respectively. Bicarbonate was determined by titration with $0.1 \mathrm{M} \mathrm{HCl}$. The NOM content was measured with the Shimadzu TOC-V $\mathrm{VSN}_{\mathrm{N}}$ Total Organic Carbon (TOC) Analyzer. 


\section{Results and Discussion}

\subsection{Effect of $p H$ on Adsorption}

The previously published relevant experimental results [8] showed the good adsorption efficiency of Se(IV) by several iron oxy-hydroxides, achieving residual concentrations at sub-ppb level within the common $\mathrm{pH}$ range (6-8), existing in most natural waters [8]. In contrast, the respective uptake capacity for the case of $\mathrm{Se}(\mathrm{VI})$ was verified as extremely low and almost zero for some of the examined adsorbents. To clarify further the $\mathrm{pH}$ effect, regarding the selective adsorption of Se(IV) only, $2 \mathrm{~g} \mathrm{FeOOH} / 2.5 / \mathrm{L}$ was added to a solution containing initial concentrations either of $100 \mu \mathrm{g}$ Se(IV)/L or of $100 \mu \mathrm{g} \mathrm{Se}(\mathrm{VI}) / \mathrm{L}$ in NSF water matrix and were stirred gently for $1 \mathrm{~h}$. According to the obtained experimental results (Figure 1), equilibrium (i.e., residual) concentrations below the detection limit of $1 \mu \mathrm{g}$ Se(IV)/L were determined for $\mathrm{pH}$ values lower than 7.5 , while at higher $\mathrm{pH}$ values, the $\mathrm{Se}(\mathrm{IV})$ was not fully adsorbed/separated/removed from the aqueous solution. Figure 1 also shows that for the initial concentration of $100 \mu \mathrm{g}$ Se(VI)/L, minor adsorption/separation takes place at $\mathrm{pH}$ values lower than 7 , while at higher $\mathrm{pH}$ values, almost zero adsorption was observed, since equilibrium concentrations equal to the initial Se(VI) concentration of $100 \mu \mathrm{g} / \mathrm{L}$ were determined. In conclusion, the optimum $\mathrm{pH}$ range for the selective Se(IV) adsorption/separation is between 7 and 7.5. Thus, the experiments to verify the optimum adsorbent type, adsorbent quantity, and contact time were subsequently performed at the $\mathrm{pH}$ value of $7.3 \pm 0.2$.

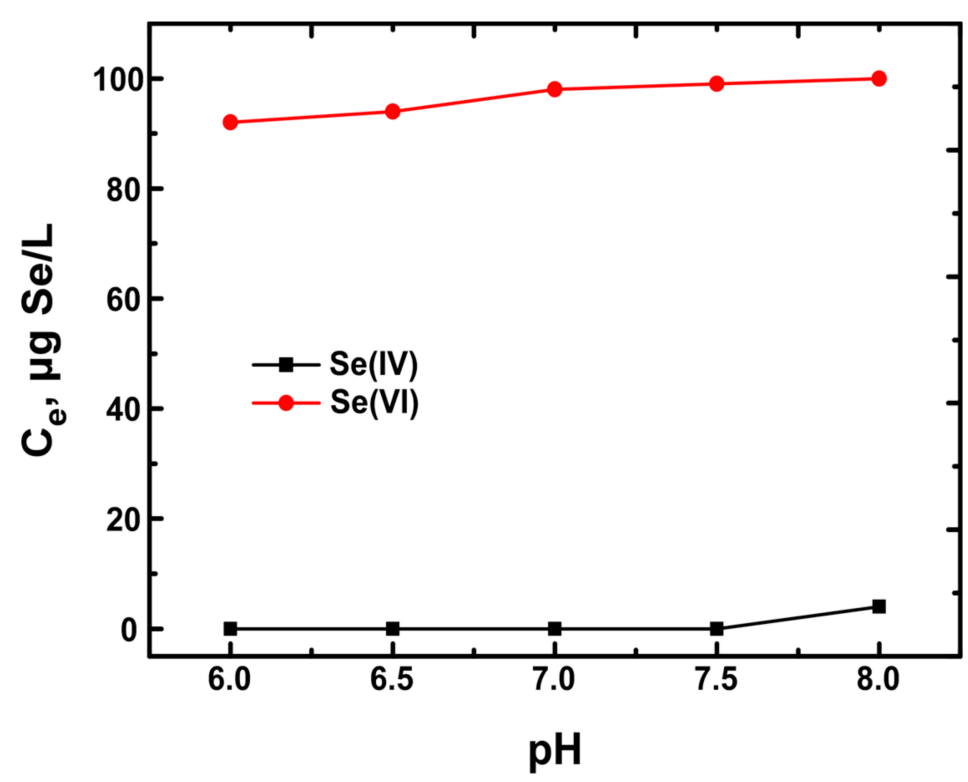

Figure 1. Effect of $\mathrm{pH}$ on adsorption of Se(IV) and Se(VI) species (examined separately), using $\mathrm{FeOOH}$ as adsorbent (synthesized at $\mathrm{pH}$ 2.5). Experimental conditions: initial concentration is $100 \mu \mathrm{g}$ $\mathrm{Se}(\mathrm{IV}) / \mathrm{L}, 100 \mu \mathrm{g} \mathrm{Se}(\mathrm{VI}) / \mathrm{L}$, adsorbent dose $2 \mathrm{~g} \mathrm{FeOOH}_{2.5} / \mathrm{L}$.

\subsection{Examined Adsorbents}

As aforementioned, the iron oxy-hydroxides were selected as sorbent materials mainly due to their good affinity against Se(IV) and poor affinity for the Se(VI) species. The FeOOHs examined for the selective adsorption of Se(IV) were those synthesized in the laboratory at different $\mathrm{pH}$ values (i.e., $\mathrm{pH}$ 2.5, 4.0, 5.7, and 8.0), as well as (for comparison reasons) the commercially available Bayoxide material. The selection of these adsorbents was based on the variation of Positive Surface Charge Density (PSCD), which ranges between 0.8 and $\left.3.2 \mathrm{mmol} \mathrm{OH}^{-}\right] / \mathrm{g}$ (Table 2), attempting to examine the relation of PSCD with the complete Se(IV) uptake (i.e., under the limits of detection) and in comparison with the respective almost null Se(VI) uptake, i.e., the selective separation between the major inorganic selenium species/oxyanions. 
Figure 2 shows the adsorption of a mixture of selenium species from a solution containing initially equal concentrations of $10 \mu \mathrm{g} \mathrm{Se}(\mathrm{IV}) / \mathrm{L}$ and of $10 \mu \mathrm{g} \mathrm{Se}(\mathrm{VI}) / \mathrm{L}$ at $\mathrm{pH}$ $7.3 \pm 0.2$. The equilibrium concentrations, i.e., the residual selenium concentrations after the adsorption procedure lower than $10 \mu \mathrm{g} / \mathrm{L}$, indicate the total adsorption of Se(IV) along with a part of $\mathrm{Se}(\mathrm{VI})$, while the equilibrium concentrations greater than $10 \mu \mathrm{g} / \mathrm{L}$ indicate the near-zero adsorption of $\mathrm{Se}(\mathrm{VI})$ along with a part of residual concentration (i.e., indicating insufficient adsorption) of Se(IV). In contrast, the equilibrium concentrations equal to $10 \mu \mathrm{g} / \mathrm{L}$ show the selective uptake/separation of only Se(IV). The adsorbents $\mathrm{FeOOH} / 2.5$ and $\mathrm{FeOOH} / 4$ showed the total uptake of Se(IV), however, with significant adsorption/separation of $\mathrm{Se}(\mathrm{VI})$ for all the examined concentrations (Figures 2-5), due to the highest PSCD values of 3.25 and $2.23 \mathrm{mmol}\left[\mathrm{OH}^{-}\right] / \mathrm{g}$, respectively (Table 2 ). In contrast, the $\mathrm{FeOOH} / 8$ with the lowest PSCD value $\left(1.04 \mathrm{mmol}\left[\mathrm{OH}^{-}\right] / \mathrm{g}\right)$ showed insufficient $\mathrm{Se}(\mathrm{IV})$ uptake. These results verify that the Positive Surface Charge Density (PSCD) is the major factor, controlling the effective selenium adsorption.

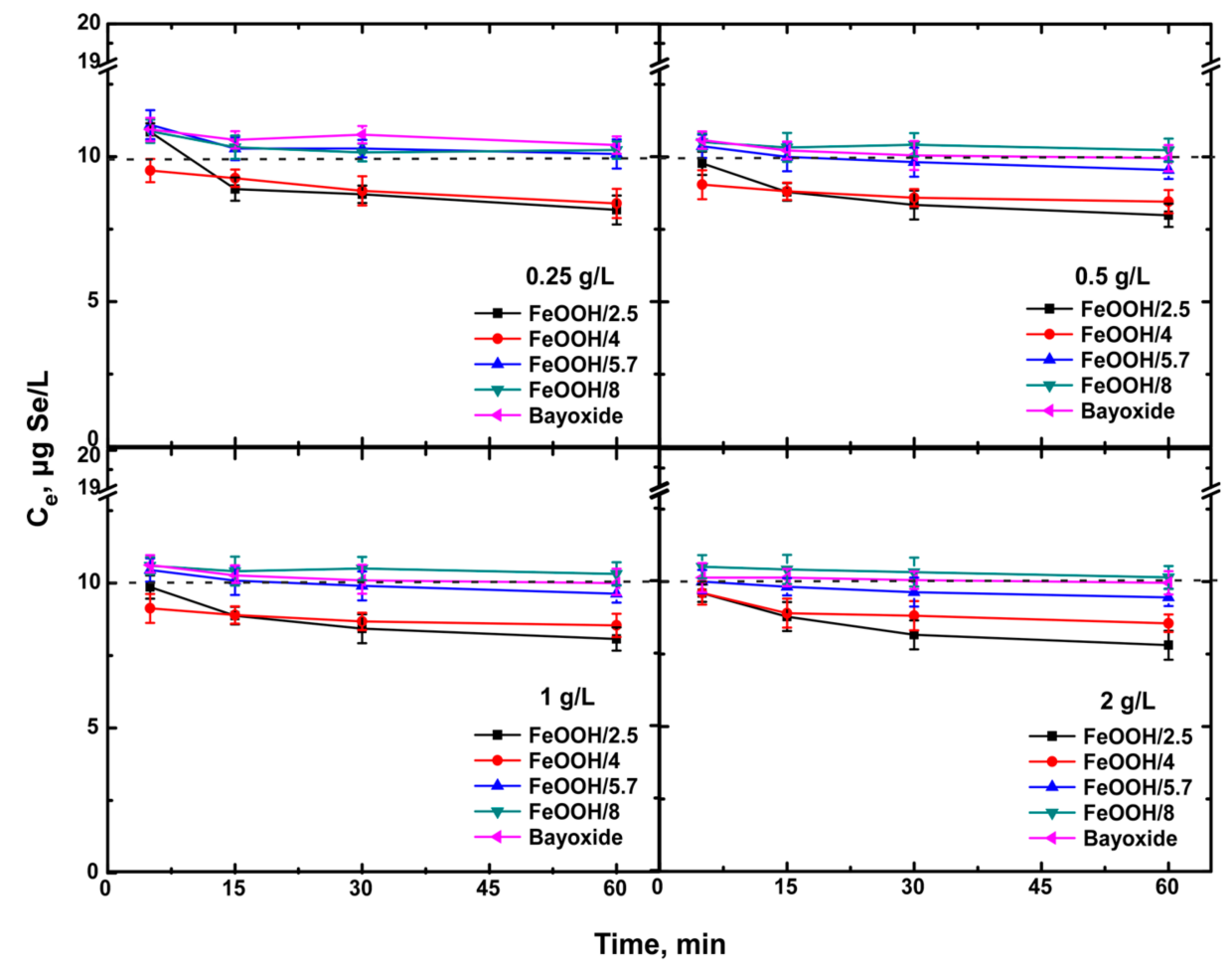

Figure 2. Adsorption of selenium species onto several FeOOHs (used as adsorbent media) in relation to the adsorbent dose and contact time. Experimental conditions: the initial concentration of Se in the samples is a mixture containing $10 \mu \mathrm{g} \mathrm{Se}(\mathrm{IV}) / \mathrm{L}$ and $10 \mu \mathrm{g} \mathrm{Se}(\mathrm{VI}) / \mathrm{L}$ (i.e., total Se $20 \mu \mathrm{g} / \mathrm{L}$ ), $\mathrm{pH} 7.3 \pm 0.2$, and temperature $20^{\circ} \mathrm{C}$. 


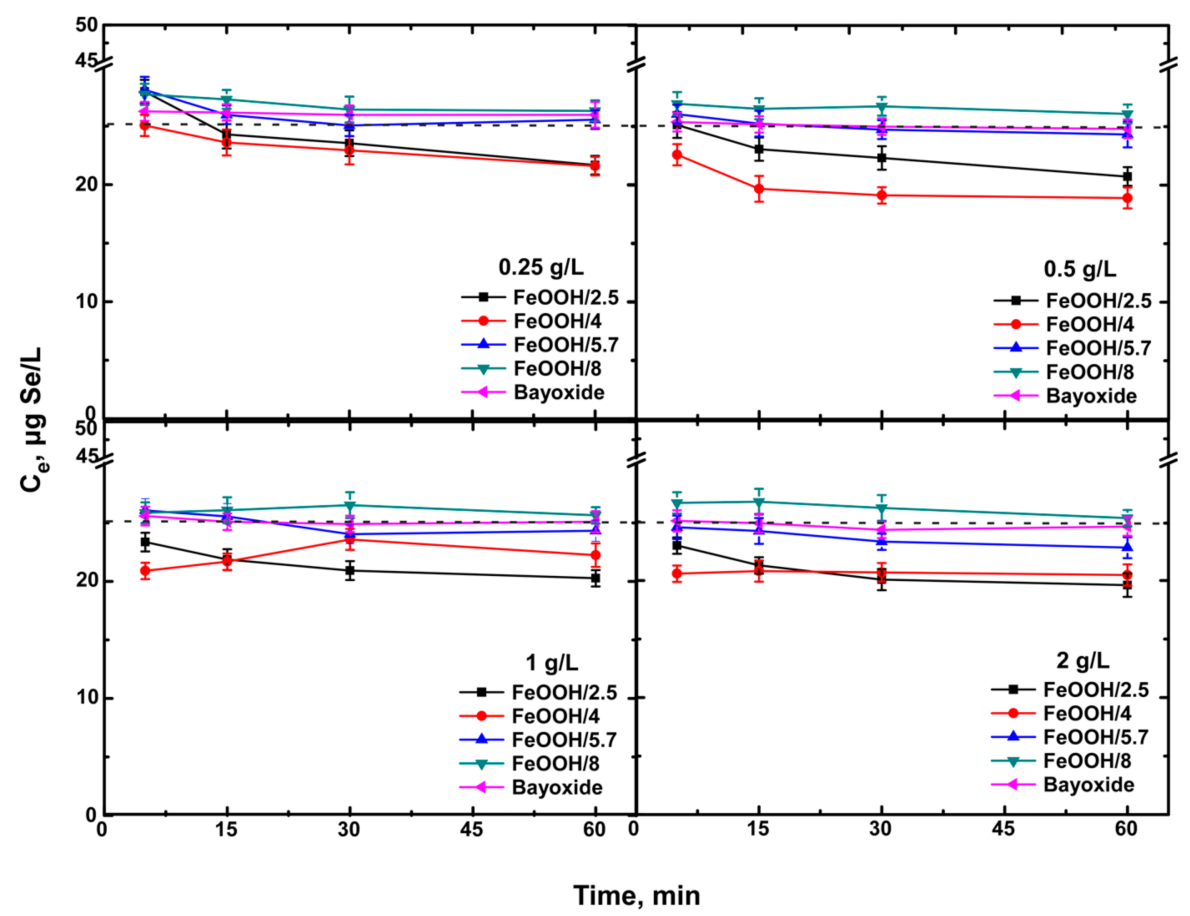

Figure 3. Adsorption of selenium species onto several FeOOHs materials in relation to the adsorbent dose and to contact time. Experimental conditions: the initial Se concentration in the samples is a mixture containing $25 \mu \mathrm{g}$ Se(IV)/L and $25 \mu \mathrm{g}$ Se(VI)/L (i.e., total Se $50 \mu \mathrm{g} / \mathrm{L}$ ), at pH $7.3 \pm 0.2$, and temperature $20^{\circ} \mathrm{C}$.

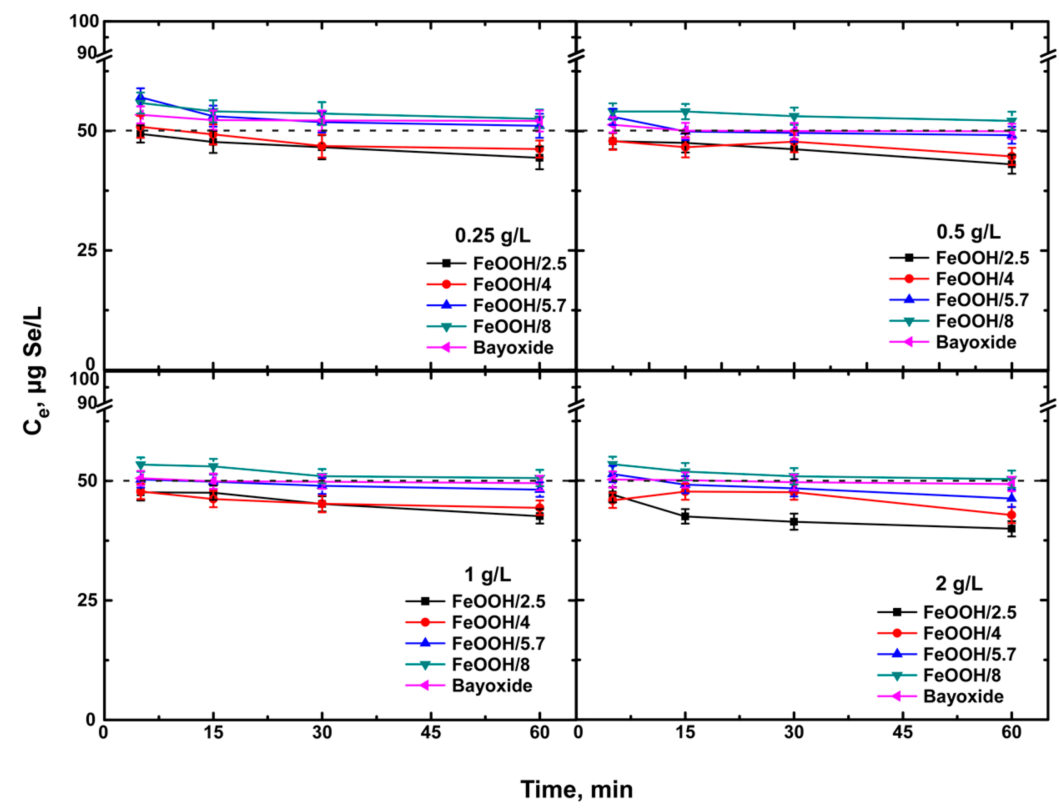

Figure 4. Adsorption of selenium species onto several FeOOHs materials in relation to adsorbent dose and to contact time. Experimental conditions: the initial concentration of samples is a mixture containing $50 \mu \mathrm{g} \mathrm{Se}(\mathrm{IV}) / \mathrm{L}$ and $50 \mu \mathrm{g} \mathrm{Se}(\mathrm{VI}) / \mathrm{L}$ (i.e., total Se $100 \mu \mathrm{g} / \mathrm{L}$ ), at $\mathrm{pH} 7.3 \pm 0.2$ and temperature $20{ }^{\circ} \mathrm{C}$. 


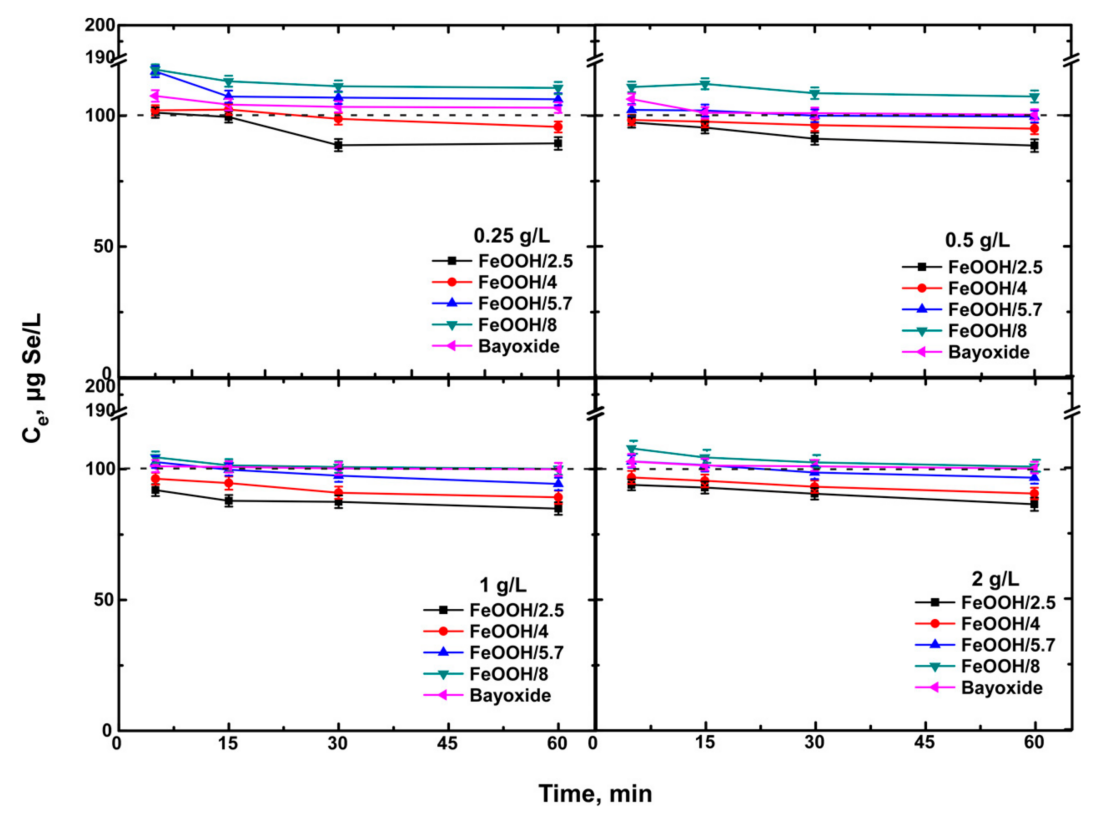

Figure 5. Adsorption of selenium species onto several FeOOHs materials in relation to adsorbent dose and to contact time. Experimental conditions: the initial concentration in the samples is a mixture containing $100 \mu \mathrm{g}$ Se(IV)/L and $100 \mu \mathrm{g}$ Se(VI)/L (i.e., total Se $200 \mu \mathrm{g} / \mathrm{L}$ ), at pH $7.3 \pm 0.2$ and temperature $20^{\circ} \mathrm{C}$.

Considering the influence of different adsorbent doses (Figure 2):

- At the lower dose of $0.25 \mathrm{~g} / \mathrm{L}$, the adsorbents with the relatively lower PSCD values (i.e., $\mathrm{FeOOH} / 5.7, \mathrm{FeOOH} / 8$, and Bayoxide) resulted in the partial adsorption of Se(IV), whereas the adsorbents with the higher PSCD values (i.e., $\mathrm{FeOOH} / 2.5$ and $\mathrm{FeOOH} / 4$ ) showed the adsorption/separation of both Se species.

- At the higher doses of $0.5,1$, and $2 \mathrm{~g} / \mathrm{L}$, the $\mathrm{FeOOH} / 8$ showed the insufficient uptake of Se(IV), whereas the Bayoxide presented complete Se(IV) uptake. In contrast, the adsorbents $\mathrm{FeOOH} / 2.5, \mathrm{FeOOH} / 4$, and $\mathrm{FeOOH} / 5.7$ showed the adsorption of both species.

- The relative standard deviation of selenium species adsorption was under $5 \%$ (i.e., RSD $<5 \%$ ) for all these experiments.

Aiming to investigate the selective adsorption of Se(IV) at different naturally occurring concentrations of selenium, relevant experiments were conducted also in NSF water matrix, but by increasing equally the initial concentrations of selenium at $25 \mu \mathrm{g} \mathrm{Se}(\mathrm{IV}) / \mathrm{L}$ and $25 \mu \mathrm{g}$ $\mathrm{Se}(\mathrm{VI}) / \mathrm{L}$ (Figure 3), $50 \mu \mathrm{g} \mathrm{Se}(\mathrm{IV}) / \mathrm{L}$ and $50 \mu \mathrm{g} \mathrm{Se}(\mathrm{VI}) / \mathrm{L}$ (Figure 4), and $100 \mu \mathrm{g} \mathrm{Se}(\mathrm{IV}) / \mathrm{L}$ and $100 \mu \mathrm{g} \mathrm{Se}(\mathrm{VI}) / \mathrm{L}$ (Figure 5). The obtained results were similar to those presented in Figure 2 for the equal initial concentrations of $10 \mu \mathrm{g} \mathrm{Se}(\mathrm{IV}) / \mathrm{L}$ and $10 \mu \mathrm{g} \mathrm{Se}(\mathrm{VI}) / \mathrm{L}$, i.e.,

- FeOOHs with the higher PSCD values can adsorb both selenium species at any examined concentration/adsorbent dose.

- $\mathrm{FeOOH} / 8$ partially adsorbs Se(IV) at any adsorbent dose.

- When using the quantities 0.5 and $1 \mathrm{~g} / \mathrm{L}$, the adsorbents $\mathrm{FeOOH} / 5.7$ and Bayoxide can completely adsorb/separate Se(IV), while at the higher dose of $2 \mathrm{~g} / \mathrm{L}$, they can also adsorb a part of Se(VI).

- At the quantities 0.5 and $1 \mathrm{mg} / \mathrm{L}$, Bayoxide demonstrated the complete adsorption of only $\mathrm{Se}^{\mathrm{IV}}$ (and not of $\mathrm{Se}^{\mathrm{VI}}$ ) within 30 min of contact time.

Conclusively, based on the results shown in Figures 2-5, Bayoxide proved to be the optimal adsorbent for the selective adsorption of Se(IV), when applying the following experimental conditions: adsorbent dose $0.5 \mathrm{~g} / \mathrm{L}$, initial selenium concentration range $10-100 \mu \mathrm{g} / \mathrm{L}$ (for a mixture of both species), contact time $30 \mathrm{~min}, \mathrm{pH} 7.3 \pm 0.2$, and temperature $20{ }^{\circ} \mathrm{C}$ with $\mathrm{RSD}<5 \%$. 
The different initial concentrations of Se(IV) and of Se(VI) in NSF water samples were subsequently examined to verify the selective adsorption of $\mathrm{Se}(\mathrm{IV})$ by the qualified adsorbent Bayoxide. Figure 6 presents the data regarding the selective adsorption of $\mathrm{Se}(\mathrm{IV})$ in water samples, containing $100 \mu \mathrm{g} / \mathrm{L}$ total selenium, for the Bayoxide doses of $0.5,0.7$, and $1 \mathrm{~g} / \mathrm{L}$ at $\mathrm{pH} 7.3 \pm 0.2$ and $30 \mathrm{~min}$ contact time. The experimental results indicate that the selective separation (and speciation) of selenium species can be effectively achieved in the aforementioned optimized conditions using the $0.5 \mathrm{~g} / \mathrm{L}$ Bayoxide dose. The equilibrium concentrations, i.e., the residual concentrations of dissolved selenium, correspond to the initial concentrations of $\mathrm{Se}(\mathrm{VI})$ in the examined water samples, indicating indirectly that only the Se(IV) was able to be completely adsorbed (and separated) by the applied adsorbent from the aqueous mixtures of selenium species.

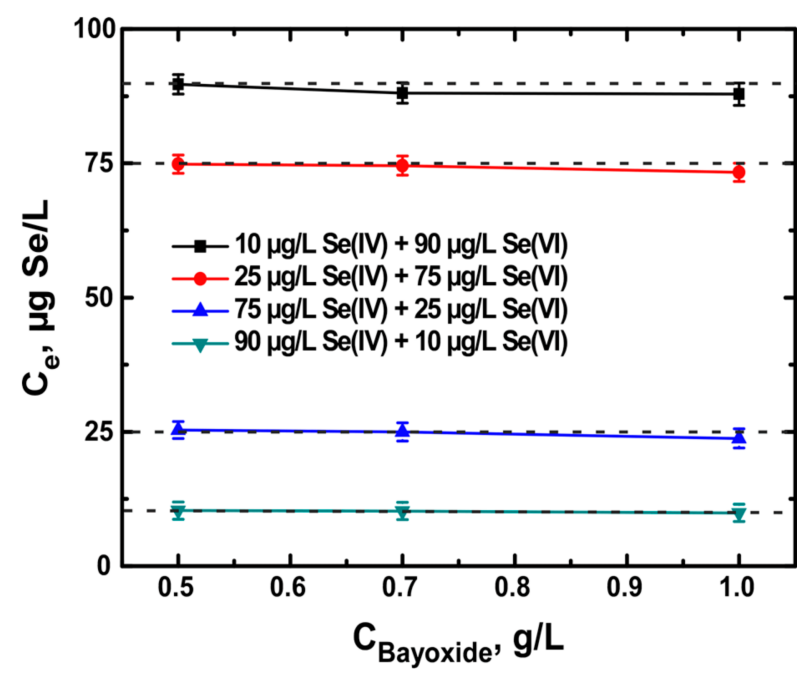

Figure 6. Equilibrium concentration of total Se, after the adsorption of selenium species mixtures in relation to Bayoxide dose. Experimental conditions: the total initial concentration of Se is $100 \mu \mathrm{g} / \mathrm{L}$, but using different ratios between the concentrations of examined Se(IV) and Se(VI) species at $\mathrm{pH}$ $7.3 \pm 0.2$, temperature $20^{\circ} \mathrm{C}$ and contact time $30 \mathrm{~min}$.

3.3. Effect of Different Commonly Co-Existing Ions on the Selective Adsorption of Se(IV), Using the Bayoxide Material

It is well known that the physicochemical characteristics of natural waters can vary widely. Thus, different concentrations ranges of the main co-existing ions were also examined, aiming to determine their potential influence on the Se(VI) lack of adsorption/separation, when using the qualified adsorbent Bayoxide and in the presence of initial $\mathrm{Se}(\mathrm{VI})$ concentration range of $10-100 \mu \mathrm{g} / \mathrm{L}$.

All these experiments were conducted in triplicate, applying the following optimum conditions: Bayoxide adsorbent dose $0.5 \mathrm{~g} / \mathrm{L}, \mathrm{pH} 7.3 \pm 0.2$, and contact time $30 \mathrm{~min}$. The examined samples were prepared in NSF water matrix (Table 1) with the additional concentrations of 25,50, 100, and $200 \mathrm{mg} / \mathrm{L}$ for $\mathrm{Cl}^{-}, \mathrm{HCO}_{3}{ }^{-}, \mathrm{NO}_{3}{ }^{-}, \mathrm{SO}_{4}{ }^{2-}, \mathrm{Ca}^{2+}, \mathrm{Mg}^{2+}$, $\mathrm{Na}^{+}$, as well as of 10, 25,40, and $50 \mathrm{mg} / \mathrm{L}$ for the case of $\mathrm{Si}$ and 1, 2.5, 4, and $5 \mathrm{mg} / \mathrm{L}$ of humic acids (NOM), measured as $\mathrm{mg}$ TOC/L, simulating the different concentration ranges of the aforementioned components, commonly existing in most natural waters. Iron was also examined with the additional concentrations of $0.1,0.250 .5$, and $1 \mathrm{mg} \mathrm{Fe}^{2+} / \mathrm{L}$, since only $\mathrm{Fe}^{2+}$ is the soluble form in anaerobic natural groundwater at the common concentration range of $0-1 \mathrm{mg} / \mathrm{L}$. All the performed adsorption experiments resulted in equilibrium/residual Se(VI) concentrations very close to the initial ones within the RSD of 3\% (Figures 7-9), therefore, verifying the almost zero selectivity of the qualified adsorbent against the Se(VI). 


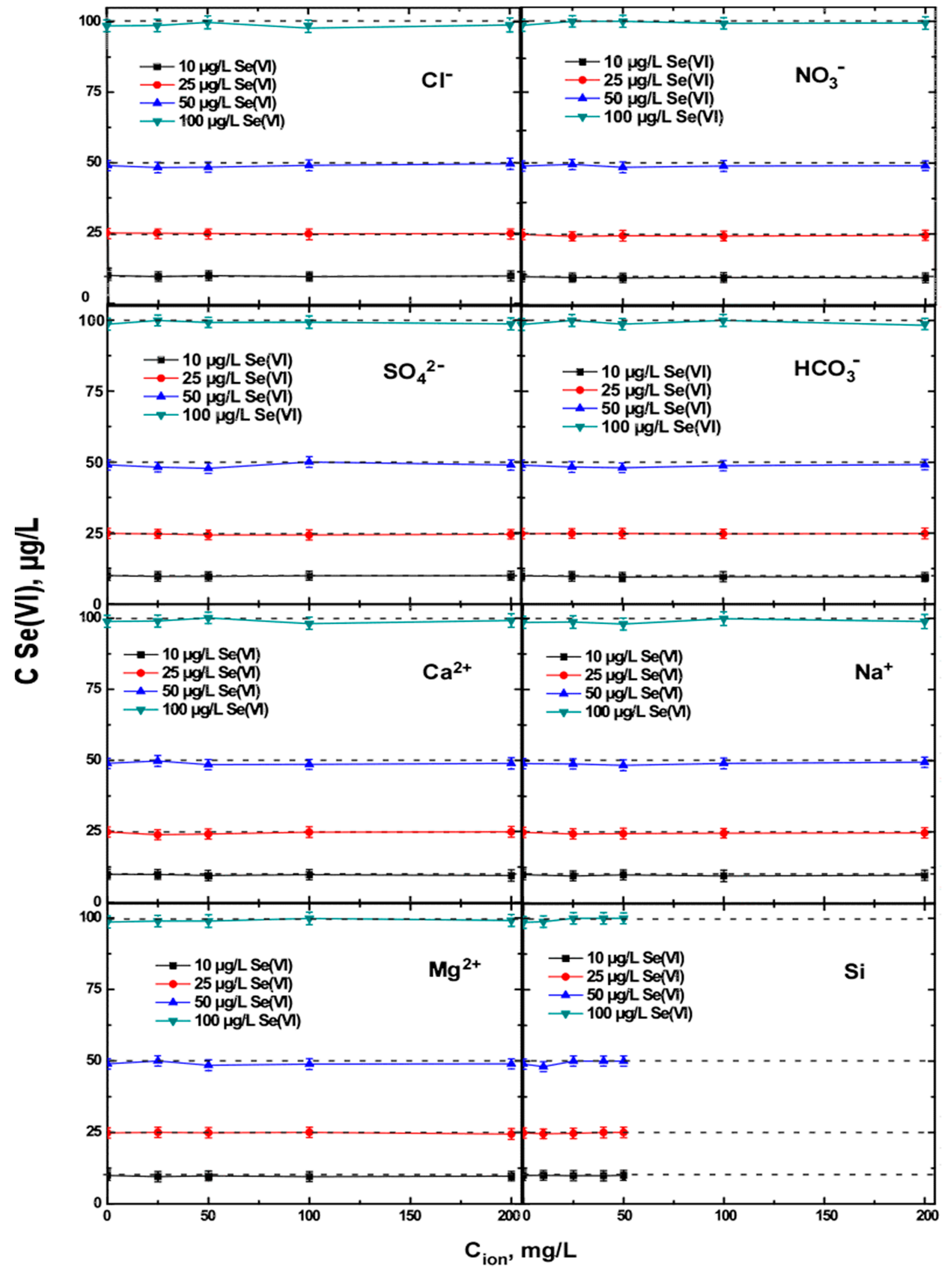

Figure 7. Influence of common water ions on the Se(VI) adsorption by Bayoxide. Experimental conditions: Bayoxide concentration $0.5 \mathrm{~g} / \mathrm{L}$, initial Se(VI) concentration range $10-100 \mu \mathrm{g} / \mathrm{L}, \mathrm{pH} 7.3 \pm 0.2$, temperature $20^{\circ} \mathrm{C}$, and contact time $30 \mathrm{~min}$. 


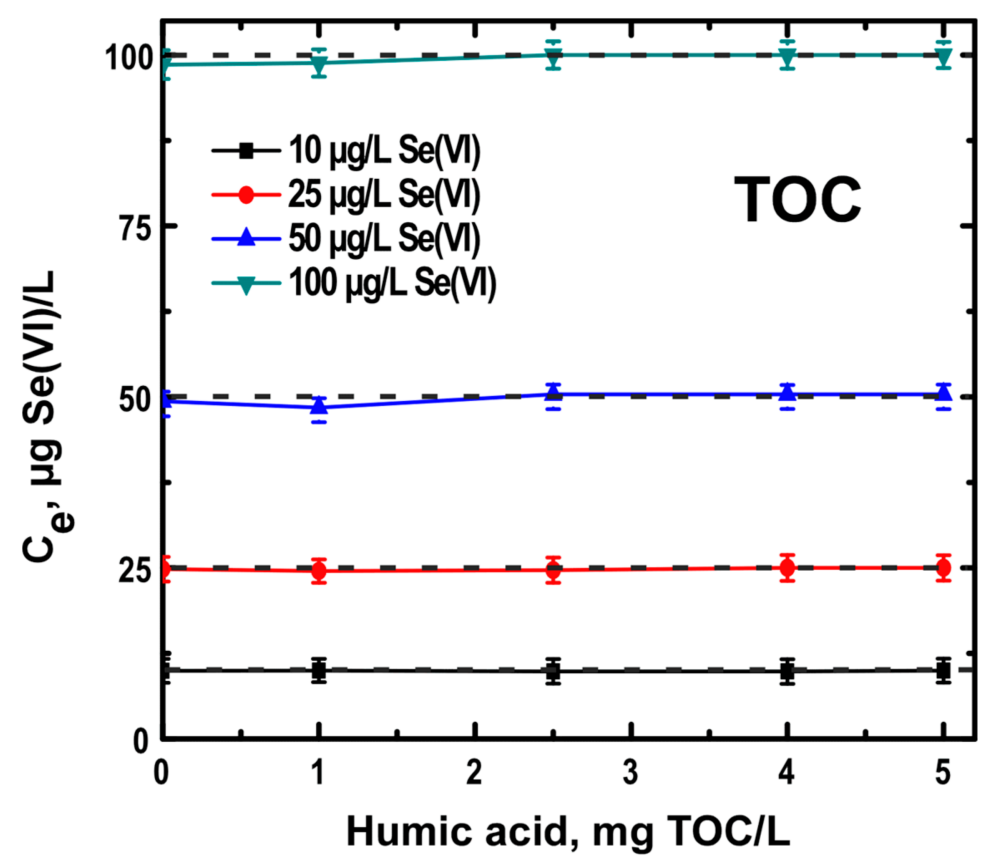

Figure 8. Influence of commonly found in natural waters NOM concentrations (as determined by TOC) on Se(VI) adsorption by Bayoxide. Experimental conditions: Bayoxide concentration $0.5 \mathrm{~g} / \mathrm{L}$, initial Se (VI) concentration range $10-100 \mu \mathrm{g} / \mathrm{L}, \mathrm{pH} 7.3 \pm 0.2$, temperature $20^{\circ} \mathrm{C}$, and contact time $30 \mathrm{~min}$.

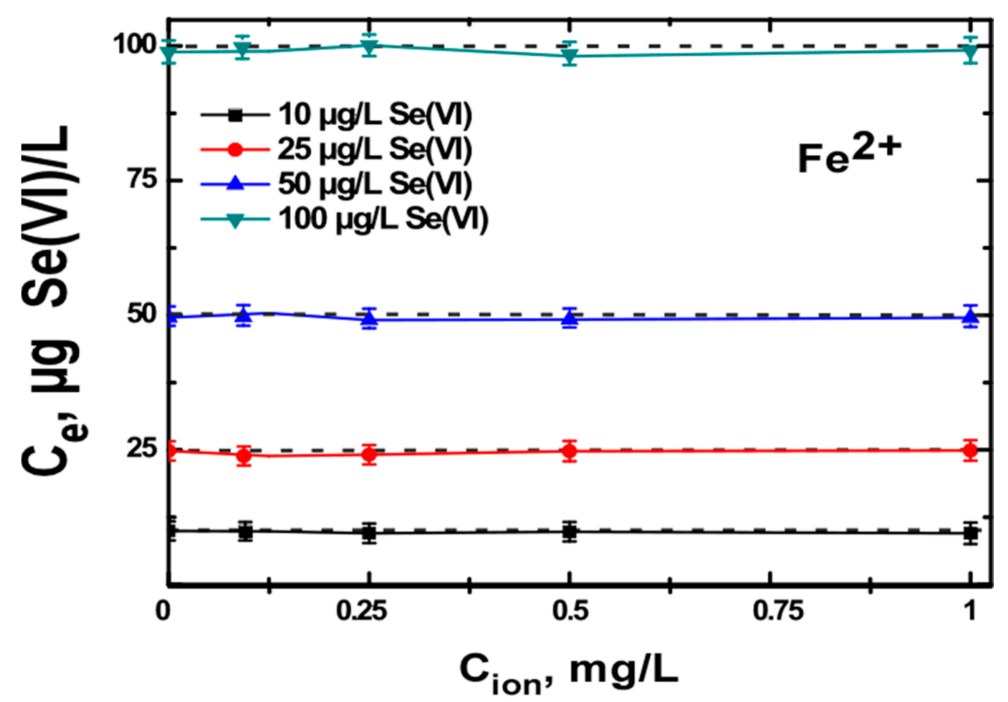

Figure 9. Influence of iron found in natural waters on Se(VI) adsorption by Bayoxide. Experimental conditions: Bayoxide concentration $0.5 \mathrm{~g} / \mathrm{L}$, initial Se(VI) concentration range of $10-100 \mu \mathrm{g} / \mathrm{L}, \mathrm{pH}$ $7.3 \pm 0.2$, temperature $20^{\circ} \mathrm{C}$, and contact time $30 \mathrm{~min}$.

In contrast, all the adsorption experiments with Se(IV) resulted in equilibrium/residual concentrations below the method's detection limit $(1 \mu \mathrm{g} / \mathrm{L})$ - see also Figures S1-S3 in the Supplementary Material, thus verifying the complete uptake/separation of Se(IV). Therefore, the effective adsorption, separation, and determination of main inorganic selenium species were not influenced from the presence of major commonly co-existing ions and for the concentration ranges usually found in natural waters.

\section{Conclusions}

A novel analytical method for the efficient speciation/determination of major (inorganic) selenium species/oxyanions, i.e., $\mathrm{Se}(\mathrm{IV})-\mathrm{SeO}_{3}{ }^{2-}$ and $\mathrm{Se}(\mathrm{VI})-\mathrm{SeO}_{4}{ }^{2-}$, in natural 
waters was developed by employing the selective adsorption of Se(IV) onto several FeOOHs materials. The examined FeOOHs showed good adsorption affinity but only for the case of Se(IV), resulting in equilibrium/residual concentrations below the analytical detection limit of $1 \mu \mathrm{g} / \mathrm{L}$, irrespective of the initial concentration range (between 10 and $100 \mu \mathrm{g} / \mathrm{L}$ ). Regarding the Se(VI) adsorption, the FeOOHs with the highest PSCD values showed low adsorption capacity for $\mathrm{SeO}_{4}{ }^{2-}$, while the $\mathrm{FeOOH} / 8$ and the Bayoxide with the lowest PSCD values and at the dose range $0.5-2 \mathrm{~g} \mathrm{FeOOH} / \mathrm{L}$, resulted in almost zero adsorption capacity.

The optimum adsorbent for the selective Se(IV) adsorption was found to be the Bayoxide material by applying the following experimental parameters: adsorbent dose $0.5 \mathrm{~g} / \mathrm{L}$, $\mathrm{pH} 7.3 \pm 0.2$, temperature $20{ }^{\circ} \mathrm{C}$, and contact time $30 \mathrm{~min}$. The presence of other ions, such as $\mathrm{Cl}^{-}, \mathrm{HCO}_{3}{ }^{-}, \mathrm{NO}_{3}{ }^{-}, \mathrm{SO}_{4}{ }^{2-}, \mathrm{Ca}^{2+}, \mathrm{Mg}^{2+}$, and $\mathrm{Na}^{+}$, commonly co-existing in natural water in the concentration range $0-200 \mathrm{mg} / \mathrm{L}$, as $\mathrm{Si}$ in the concentration range $0-50 \mathrm{mg} / \mathrm{L}$ and as humic acid (NOM) in the concentration range $0-5 \mathrm{mg} / \mathrm{L}$ (as TOC), as well as of $\mathrm{Fe}^{2+}$ in the concentration range $0-1 \mathrm{mg} / \mathrm{L}$, did not show any interference on the quantitative selective adsorption of Se(IV) (i.e., below the detection limit) and the simultaneous nearzero adsorption capacity for $\mathrm{Se}(\mathrm{VI})$ in the concentration range of selenium species between 10 and $100 \mu \mathrm{g} / \mathrm{L}$, when the Bayoxide material was applied. Therefore, the commercially available Bayoxide provides the advantage of selective separation of selective separation of selenium oxyanions, permitting the subsequent determination of Se species using any available analytical laboratory method for total selenium determination. Furthermore, this novel speciation method is considered as low-cost, requiring simple reagents and handling procedures, and can be also potentially applied in field studies, using the appropriate simple portable determination equipment.

Supplementary Materials: The following are available online at https:/ /www.mdpi.com/2297-873 9/8/3/27/s1, Text S1, Figure S1: Influence of common water ions on Se(IV) residual concentration (due to adsorption) by the use of Bayoxide material. Experimental conditions: Bayoxide concentration $0.5 \mathrm{~g} / \mathrm{L}$, initial Se(IV) concentration range $10-100 \mu \mathrm{g} / \mathrm{L}, \mathrm{pH} 7.3 \pm 0.2$, temperature $20^{\circ} \mathrm{C}$, and contact time $30 \mathrm{~min}$., Figure S2: Influence of natural organic matter, as simulated by different humic acid concentrations, on the Se(IV) adsorption by the use of Bayoxide material. Experimental conditions: Bayoxide concentration $0.5 \mathrm{~g} / \mathrm{L}$, initial Se(IV) concentration range 10-100 $\mu \mathrm{g} / \mathrm{L}, \mathrm{pH} 7.3 \pm 0.2$, temperature $20^{\circ} \mathrm{C}$, and contact time $30 \mathrm{~min}$. Figure S3: Influence of iron found in natural waters on Se(IV) adsorption by Bayoxide. Experimental conditions: Bayoxide concentration $0.5 \mathrm{~g} / \mathrm{L}$, initial Se (IV) concentration range $10-100 \mu \mathrm{g} / \mathrm{L}, \mathrm{pH} 7.3 \pm 0.2$, temperature $20^{\circ} \mathrm{C}$, and contact time $30 \mathrm{~min}$.

Author Contributions: Investigation E.B. and K.K.; data curation K.K. and E.B. writing-original draft K.K.; methodology M.M.; resources A.Z.; project administration A.Z. and M.M.; conceptualization M.M.; supervision A.Z., M.M.; writing—review and editing A.Z. and M.M. All authors have read and agreed to the published version of the manuscript.

Funding: This research received no external funding.

Conflicts of Interest: The authors declare no conflict of interest.

\section{References}

1. Pettine, M.; McDonald, T.J.; Sohn, M.; Anquandah, G.A.K.; Zboril, R.; Sharma, V.K. A critical review of selenium analysis in natural water samples. Trends Environ. Anal. Chem. 2015, 5, 1-7. [CrossRef]

2. WHO. Guidelines for Drinking-Water Quality: Fourth Edition Incorporating the First Addendum; WHO: Geneva, Switzerland, 2017. [CrossRef]

3. EPA. 2018 Edition of the Drinking Water Standards and Health Advisories Tables; Office of Water, US Environmental Protection Agency: Washington, DC, USA, 2018.

4. The Council of the European Union. Council Directive 98/93/EC of November 1998 on the Equality of Water Intended for Human Consumption; Official Journal of the European Communities: Luxembourg, 1988.

5. Vinceti, M.; Vicentini, M.; Wise, L.A.; Sacchettini, C.; Malagoli, C.; Ballotari, P.; Filippini, T.; Malavolti, M.; Rossi, P.G. Cancer incidence following long-term consumption of drinking water with high inorganic selenium content. Sci. Total Environ. 2018, 635, 390-396. [CrossRef] 
6. He, M.; Su, S.; Chen, B.; Hu, B. Simultaneous speciation of inorganic selenium and tellurium in environmental water samples by polyaniline functionalized magnetic solid phase extraction coupled with ICP-MS detection. Talanta 2020, 207, 120314. [CrossRef] [PubMed]

7. Sentkowska, A.; Pyrzynska, K. Hydrophilic interaction liquid chromatography in the speciation analysis of selenium. J. Chromatogr. B Anal. Technol. Biomed. Life Sci. 2018, 1074-1075, 8-15. [CrossRef]

8. Kalaitzidou, K.; Nikoletopoulos, A.; Tsiftsakis, N.; Pinakidou, F.; Mitrakas, M. Adsorption of Se(IV) and Se(VI) species by iron oxy-hydroxides: Effect of positive surface charge density. Sci. Total Environ. 2019, 687, 1197-1206. [CrossRef] [PubMed]

9. Santos, S.; Ungureanu, G.; Boaventura, R.; Botelho, C. Selenium contaminated waters: An overview of analytical methods, treatment options and recent advances in sorption methods. Sci. Total Environ. 2015, 521-522, 246-260. [CrossRef]

10. Barabas, S.; Cooper, W.C. Volumetric determination of selenium. Anal. Chem. 1956, 28, 129-130. [CrossRef]

11. Ooba, S.; Uneo, S. Gravimetric determination of selenium from perchloric acid solution with hydrazine. Talanta 1975, $22,51-55$. [CrossRef]

12. Bagheri, N.; Saraji, M. Combining gold nanoparticle-based headspace single-drop micro-extraction and a paper-based colorimetric assay for selenium determination. Anal. Bioanal. Chem. 2019, 411, 7441-7449. [CrossRef]

13. Tavancheh, M.; Beiraghi, A. Spectrophotometric Determination of Selenium (IV) Using 4,5-diamino-o-xylene as a New Chromogenic Reagent. Adv. J. Chem. A 2020, 3, 15-23. [CrossRef]

14. Suzuki, Y.; Hashigaya, N.; Kawakubo, S. Development of a simple and low-cost device for fluorometric determination of selenium in water samples. Anal. Sci. 2010, 26, 719-726. [CrossRef]

15. Ali, J.; Tuzen, M.; Kazi, T.G. Developed of a Green Water Switchable Liquid-Liquid Microextraction Method for Assessment of Selenium in Food and Soft Drink Samples by Using Hydride Generation Atomic Absorption Spectrometry. Food Anal. Methods 2019, 12, 1298-1307. [CrossRef]

16. Da Luz Potes, M.; Venâncio Nakadi, F.; Grasel Frois, C.F.; Rodrigues Vale, M.G.; Messias da Silva, M. Investigation of the conditions for selenium determination by photochemical vapor generation coupled to graphite furnace atomic absorption spectrometry. Microchem. J. 2019, 147, 324-332. [CrossRef]

17. Nyaba, L.; Matong, J.M.; Dimpe, K.M.; Nomngongo, P.N. Speciation of inorganic selenium in environmental samples after suspended dispersive solid phase micro-extraction combined with inductively coupled plasma spectrometric determination. Talanta 2016, 159, 174-180. [CrossRef]

18. Liu, Y.; He, M.; Chen, B.; Hu, B. Simultaneous speciation of inorganic arsenic, selenium and tellurium in environmental water samples by dispersive liquid micro-extraction combined with electrothermal vaporization inductively coupled plasma mass spectrometry. Talanta 2015, 142, 213-220. [CrossRef] [PubMed]

19. Kleckner, A.E.; Kakouros, E.; Robin Stewart, A. A practical method for the determination of total selenium in environmental samples using isotope dilution-hydride generation inductively coupled plasma-mass spectrometry. Limnol. Oceanogr. Methods 2017, 15, 363-371. [CrossRef]

20. Martínez-Bravo, Y.; Roig-Navarro, A.F.; López, F.J.; Hernández, F. Multielemental determination of arsenic, selenium and chromium(VI) species in water by high-performance liquid chromatography-inductively coupled plasma mass spectrometry. $J$. Chromatogr. A 2001, 926, 265-274. [CrossRef]

21. Wilschefski, S.; Matthew, B. Inductively Coupled Plasma Mass Spectrometry: Introduction to Analytical Aspects. Clin. Biochem. Rev. 2019, 40, 115-133. [CrossRef]

22. Omanović, E.; Moderreger, H.; Kalcher, K. Determination of selenium in drinking water with a simple field device. Anal. LetT 2002, 35, 943-958. [CrossRef]

23. Deng, B.; Feng, J.; Meng, J. Speciation of inorganic selenium using capillary electrophoresis-inductively coupled plasma-atomic emission spectrometry with on-line hydride generation. Anal. Chim. Acta 2007, 583, 92-97. [CrossRef] [PubMed]

24. Kumkrong, P.; LeBlanc, K.L.; Mercier, P.H.J.; Mester, Z. Selenium analysis in waters. Part 1: Regulations and standard methods. Sci. Total Environ. 2018, 640-641, 1611-1634. [CrossRef]

25. LeBlanc, K.L.; Kumkrong, P.; Mercier, P.H.J.; Mester, Z. Selenium analysis in waters. Part 2: Speciation methods. Sci. Total Environ. 2018, 640-641, 1635-1651. [CrossRef]

26. Zelmanov, G.; Semiat, R. Selenium removal from water and its recovery using iron (Fe3+) oxide/hydroxide-based nanoparticles sol (NanoFe) as an adsorbent. Sep. Purif. Technol. 2013, 103, 167-172. [CrossRef]

27. Gonzalez, C.M.; Hernandez, J.; Peralta-Videa, J.R.; Botez, C.E.; Parsons, J.G.; Gardea-Torresdey, J.L. Sorption kinetic study of selenite and selenate onto a high and low pressure aged iron oxide nanomaterial. J. Hazard. Mater. 2012, 211-212, 138-145. [CrossRef]

28. Rovira, M.; Giménez, J.; Martínez, M.; Martínez-Lladó, X.; De Pablo, J.; Martí, V.; Duro, L. Sorption of seleni-um(IV) and selenium(VI) onto natural iron oxides: Goethite and hematite. J. Hazard. Mater. 2008, 150, 279-284. [CrossRef]

29. Lo, S.L.; Chen, T.Y. Adsorption of Se(IV) and Se(VI) on an iron-coated sand from water. Chemosphere 1997, 35, 919-930. [CrossRef]

30. Balistrieri, L.S.; Chao, T.T. Adsorption of selenium by amorphous iron oxyhydroxide and manganese dioxide. Geochim. Cosmochim. Acta 1990, 54, 739-751. [CrossRef]

31. Das, S.; Jim Hendry, M.; Essilfie-Dughan, J. Adsorption of selenate onto ferrihydrite, goethite, and lepidocrocite under neutral pH conditions. Appl. Geochem. 2013, 28, 185-193. [CrossRef] 
32. Lounsbury, A.W.; Yamani, J.S.; Johnston, C.P.; Larese-Casanova, P.; Zimmerman, J.B. The role of counter ions in nano-hematite synthesis: Implications for surface area and selenium adsorption capacity. J. Hazard. Mater. 2016, 310, 117-124. [CrossRef]

33. Amy, G.; Chen, H.W.; Drizo, A.; Von Gunten, U.; Brandhuber, P.; Hund, R.; Chowdhury, Z.; Kommineni, S.; Sinha, S.; Jekel, M.; et al. Adsorbent Treatment Technologies for Arsenic Removal; AWWA Research Foundation and American Water Works Association: Washington, DC, USA, 2005.

34. Tresintsi, S.; Simeonidis, K.; Vourlias, G.; Stavropoulos, G.; Mitrakas, M. Kilogram-scale synthesis of iron oxy-hydroxides with improved arsenic removal capacity: Study of Fe(II) oxidation-precipitation parameters. Water Res. 2012, 46, 5255-5267. [CrossRef] [PubMed]

35. Kosmulski, M. Surface Charging and Points of Zero Charge, Surface Charging and Points of Zero Charge, 1st ed.; CRC Press: Boca Raton, FL, USA, 2009. [CrossRef]

36. Ahmed, M.J.; Islam, M.T.; Nime, M.J. A highly selective and sensitive spectrophotometric method for the determination of selenium using 2-hydroxy-1-napthaldehyde-orthoaminophenol. Anal. Methods 2015, 7, 7811-7823. [CrossRef] 